\title{
THE MEDIATING EFFECT OF BRAND TRUST ON THE INFLUENCE OF COMMUNICATION, PRICE, AND PRODUCT QUALITY ON CONSUMER PURCHASE BEHAVIOUR IN A LESS-DEVELOPED COUNTRY
}

\author{
JAMAL MOHAMMED ESMAIL AL-EKAM \\ School of Business Management \\ Universiti Utara Malaysia
}

\begin{abstract}
Brand trust is one of the key elements in brand building and securing customer loyalty, based on relationship marketing factors. The aim of this research was to examine the influence of perceived product price, perceived product quality and communication on brand trust, and the effect of brand trust on consumer purchase behaviour based on the relationship theory perspective. The research instrument was developed based on items taken from previous studies. Questionnaires were distributed to 1400 consumers in 10 primary and secondary schools in three towns in Sanaa, Ibb, and Aden in Yemen. Only 711 questionnaires were used for statistical analysis, using Partial Least Squares (PLS-SEM). Results indicated that trust has a positive significant impact on purchase behaviour. Trust is also a mediator between communication and purchase behaviour, and between perceived quality and purchase behaviour. In addition, this study showed that both perceived product quality and communication positively influence building brand trust. The constructed model has a good goodness-of-fit index. This research also discussed practical implications and applications in developing and less-developed countries.
\end{abstract}

Keywords: Building brand trust, perceived quality, perceived communication, brand trust to purchase behaviour

\section{Introduction}

In developed countries, consumers are inclined to purchase local brands, but in developing and less-developed countries, consumers usually prefer imported brands (Agbonifoh \& Elimimian, 1999; Al-Ekam, 2013; Batra, Ramaswamy, Alden, Steenkamp \& Ramachander, 2000; Wang $\&$ Chen, 2004). In line with this state of affairs, several authors (Ahmed, Johnson, Yang, Fatt, Teng, \& Boon, 2004) confirmed that consumers in a developed economy have a tendency to purchase domestic brands first, followed by brands from other developed countries, and goods from less-developed countries.

Hence, there is a low brand trust that would induce the purchase of local brands in Yemen, as evidenced by the increase in imported brands. For example, 2010 saw an increase in imported brands of $7.9 \%$ from 2009 (Central Bank of Yemen, 2010). Additionally according to AlEkam (2013), Yemeni consumers prefer foreign brands due to the influx of those brands into the country.

Therefore, there is a lack of marketing factors as observed by Al-Ekam, Mat Salleh, Baharom, Teh, Noh and Hussain (2012), who stated that, "local brands of developing or the less-developed countries do not have much popularity in the society". This is because the marketing factors, communication, perceived price, perceived quality, and trust have not been adapted well by the local brands; hence, consumers are not 
familiar with the brands and are unpatriotic to the local brands. Most past studies showed that marketing factors appear to play a positive and significant role in purchase behaviour of local brands (Han, 1988). However, in developing or the less-developed countries, there is a lack of studies on patriotism among developing or the less-developed consumers (Al-Ekam, 2013). Hence, this study examined the influence of marketing factors (product price, perceived product quality, and communication) on brand trust. Subsequently, it examined the influence of brand trust on consumer purchase behaviour, based on the relationship theory perspective.

\section{Brand Trust and Purchase Behaviour}

Trust is not an automatic factor, but hinges upon the relation between two parties. Along a similar line of thinking, past researchers (Anderson \& Weitz, 1989; Ganesan, 1994; Rousseau, Sitkin, Burt, \& Camerer, 1998) revealed that trust depends on the inclination of the person to leave himself vulnerable to another person. However, customer trust relies on a firm's reliability and attributes that urge the customers to trust its brands. Based on a study by Moorman et al. (1993), trust stems from customer satisfaction with a firm's reliability, public relations, and know-how. Moreover, various studies also revealed that trust plays a role in the purchase behaviour of local or foreign brands (Anderson \& Weitz, 1989; Moorman, Deshpande \& Zaltman, 1993; Morgan \& Hunt, 1994; Sirdeshmukh, Singh \& Sabol, 2002).

Various issues arise in relationship marketing theory, including the development of trust. Critical factors that trust depends on include a firm's country of origin, stakeholders, and managers that call for the utilisation of various incentives that promote the perceptions of the firm's reliability in global markets. For the development of trust, the inclination of a firm to expose its reliability to the consumers is essential for trust-building (Moorman, Deshpande \& Zaltman, 1993; Morgan \& Hunt, 1994).

The existence of a lack of trust stems from a firm's behaviour that leads customers to either trust or distrust its brands. In Yemen, consumers are inclined to be exposed to firms providing schemes to consumers of their brands. Patriotism also reveals that trust is a critical factor impacting consumers' purchase behaviour (Al-Ekam, 2013).

Further studies to this end were recommended by Jimenez and Martın (2009), who urged the examination of other market-based factors. In addition, they also recommended that future studies need to acknowledge other instruments for gaining trust (e.g., warranties and national brand associations). A critical factor that has a personal impact is one's behaviour that facilitates the purchase of any item. Individual behaviours alter from one time to another, which may impact the present or future purchase behaviour.

Meanwhile other authors (Sirdeshmukh, Singh $\&$ Sabol, 2002) revealed that for the development of a rational exchange between two brands or individuals, competitive advantage along with a dynamic financial activity coupled with greater degrees of customer satisfaction and loyalty are needed. Trust must be developed to prevent opportunities of abuse of cooperation to crop up. According to Ganesan (1994), Rousseau, Sitkin, Burt and Camerer (1998), and Anderson and Weitz (1989), individual trust is the inclination to be vulnerable, and to be satisfied that the presence of a partnership between two people or institutions successfully works, which is reinforced by responsibility and mutual trust.

Moreover, Jimenez and Martın (2009) investigated various degrees of trust, and showed that it has a significant role in any relationship. In addition, trust is significant in building successful interactions, leading to expectations of on-going benefits and increasing customer trust (Crosby, Evans \& Cowles, 1990; Moorman, Deshpande \& Zaltman, 1993; Morgan \& Hunt, 1994).

Nevertheless, trust also hinges on other factors, including communication strategies, and marketing factors, such as communication, perceived price, perceived quality and trust, opportunistic behaviour, cultural likeness, parallel goals, satisfaction, jeopardy, brand, 
and company attributes (Hunt, Arnett \& Madhavaram, 2006; Morgan \& Hunt, 1994; Nelson, 1974; Sirdeshmukh, Singh \& Sabol, 2002). In cases where local companies decide to import goods from abroad, but have no good trading relations with developing countries as in the case of Yemen, customers generally distrust them and view their goods as having low quality. On the other hand, a reputable company would have a positive impact on consumer attitude and their purchase intention. This in turn will increase the perceived reliability of the company owing to customer trust. Although findings on the relationship between trust purchase intentions are mixed, many studies found the relationship to be significantly positive (Wu $\&$ Lo, 2009). Hence, this study postulated the following hypothesis.

H1: Trust has a significant and positive influence upon purchase behaviour.

\section{The Relationship between Communication, Perceived Price, Perceived Quality, and Trust}

McEachern, Schröder, Willock, Whitelock and Mason (2007) reported that factors of attitude stem from communication, perceived price, and perceived quality, as they have a significant effect upon customer purchasing behaviour. In other words, communication, perceived price, and perceived quality would have a positive significant effect on trust and purchase behaviour.

In a similar study in Israel, Shoham and Makovec (2003) revealed a significant positive relationship between general attitude of marketing perspectives and actual purchase behaviour. Marie et al. (2009) also reported a significant positive relationship between attitude and purchase behaviour in Belgium, while Shaw and Shiu (2003) demonstrated the same in the context of the U.K. The linkage between attitude and behaviour is the core postulation behind some models including theory of reasoned action (TRA), technology acceptance model (TAM), and others. For example, McEachern,
Schröder, Willock, Whitelock and Mason (2007) utilised the following variables in their model: purchase behaviour, trust, quality, price, and communication. The study indicated that quality and advertisement significantly and positively influence actual purchases, and they significantly and negatively relate to trust and purchase behaviour. In Lebanon, on the other hand, Farah and Newman (2010) reported that marketing factors significantly and positively influenced trust and purchase behaviour.

In a related study, Chung and Pysarchik (2000) found a positive relationship between Korean customer attitudes of marketing factors toward brand and evaluation of the brand. They also revealed a positive relationship between attitudes of consumers and their intention to purchase domestic brands. Similarly in Belgium, Marie, Patrick, Pelsmackera and Maggie (2009) reported that attitudinal antecedents of behaviour are significant predictors of purchasing behaviour, although they become insignificant once purchasing behaviour is incorporated into the model.

With regard to price, Story and Hess (2006) stated that price is one critical variable that impacts purchase behaviour. It is among the main factors that assist in the determination of decisions toward purchase behaviour. The impact of price on purchase behaviour hinges on the selection of the decisions, although other factors may also impact the two factors, including testimonials, price insensitivity, and willingness of brand or service to be the favourite. Price also determines customer loyalty to the brand and influences individual behaviour every time. Sole happiness does not predict price factors, but for customers to be happy, price is among the core determinants of happiness.

For the determination of brand price, an individual making the purchase develops a phenomenon of interest that assists in making his or her preference for a particular brand (low price), or rejection (high price). It is imperative to note that consumers perceive price as a benchmark, and thus make their decisions following a comparison of the price offered 
with the benchmark price. This happens with loyal consumers and those who are indifferent to a certain brand. The tools employed in sales promotions also impact consumer brand selection, whether local or imported. In a decision-making, consumers bear promotions in mind when they cannot decide what brand to buy between two brands that are equally attractive (Alvarez \& Casielles, 2005). In addition, local brands that require marketing may also use price as a mechanism to compete against imported brands.

Additionally, Juan and Manuel (2009) revealed that price significantly and positively relates to consumer trust and actual purchase behaviour, and maximises the effects of price promotion on consumer trust and actual purchase behaviour. Price also has a key role in consumer trust and actual purchase behaviour because the nonappearance of freight charges may lead to local manufacturers minimising their brand prices that would otherwise lead to increased prices. Other studies (Granzin \& Olsen, 1998) of the same calibre showed that price is significantly related to trust and purchase behaviour.

Moreover, firms can make use of advertisements to attract consumers to the local brands. According to a study conducted in the U.S. by Han (1988), advertisements are aimed at stimulating the demand of consumer inclination toward local brands, and it is effective in instigating responses in support for locallyproduced brands. Advertisements may be useful in changing consumer preferences for U.S. brands to local brands. However, the idea that advertisements may be used to divert consumer attraction to the U.S. brands was not effective; they are only effective with some societal groups.

Some other related studies regarding customer's psychological thinking and behaviour toward communication or advertisement revealed the interrelationship between the emotional and cognitive impact of advertisement, attitudes toward them, brand attitudes, and purchase intentions (Burke \& Edell, 1989; MacKenzie, Lutz, \& Belch, 1986; Park \& Young, 1986). It is especially true for variables such as attitude toward advertisement, advertisement credibility, advertisement perceptions, mood, and so on.

Several studies elaborated that reactions toward communications/advertisements and brand attitudes can be measured through the use of Ajzen and Fishbein (1977) expectancy value model, which reveals significant factors concerning consumer reactions (Batra, Ramaswamy, Alden, Steenkamp\& Ramachander, 2000). The main antecedents showed the outcome of attitudes stemming from advertisements with the help of a two-way mediation model (Brown \& Stayman, 1992; MacKenzie \& Lutz, 1989).

Generally, media campaigns or communication/ advertising work are measured using the acceptance method, known as the adaptation continuum, in which campaigns are floated for a particular local market effectively. Researchers advocating for this standardisation theory believe that companies that standardised themes have often led to a standard local brand image on a global scale (Jain, 1989; Kanso, 1992; Levitt, 1993). On the other hand, other authors (Synodinos, Keown, \& Jacobs, 1989) contended that advertisements having wide coverage almost always fail, owing to their overlooking of the significance of local cultures.

Similarly, Armstrong and Kotler (2009) stated that media campaigns may directly impact purchase decisions, and this can be facilitated through the provision of brand information and assisting consumer decision-making on the most optimum purchase option. In other words, if the marketing campaign is effective, then consumers would buy the brand being advertised (Armstrong \& Kotler, 2009). The approach of communication/advertising as a marketing factor was viewed by Jimenez and Martin (2009) as a ripe topic for further research.

Prior studies revealed that advertisements have a significant and positive relationship with actual purchases (McEachern, Schröder, Willock, Whitelock and Mason, 2007). Additionally, Marie et al. (2009) stated that quality is among the most important antecedents of purchase 
behaviour and it has a significant and positive relation with purchase behaviour (Al-Ekam, 2013; Batra, Ramaswamy, Alden, Steenkamp \& Ramachander, 2000; Knight, 1999; McEachern, Schröder, Willock, Whitelock \& Mason, 2007; Vida, Dmitrovic \& Obadia, 2008).

Moreover, several researchers (Dash, Schiffman \& Berenson, 1976; Lumpkin, Greenberg \& Goldstucker, 1985; Bell, Hot \& Tang, 1998) revealed a significant relationship between price, quality, and communication/advertisement, and trust. They also revealed the significance of perceived quality, pre-purchase price information, and advertisements in impacting consumers' actual purchases.

Quality is known to be among the most significant elements that assists consumers in their decision-making. Consumers decide to make a final decision when they perceive an equal balance between price and quality, in which case, the intention to purchase is increased (Elliot \& Cameron, 1994).

Hence, it can be stated that consumers are more inclined to purchase local brands in cases where they are familiar with the price, technical features, and brand name, and if they feel that the brand is of superior quality or of equal quality with imported brands. On the other hand, when consumers find local brands to be of inferior quality to the imported ones, they generally prefer to purchase the latter. This implies that there is a significant relationship between perceived brand quality, trust, and purchase behaviour, which hinges on the structures of purchase situations (Elliot \& Cameron, 1994).

In light of the above discussion, this study postulated the following hypotheses (see Figure 1 for the complete model).

H2 : Communication is significantly and positively related to trust.

H3 : Perceived price is significantly and positively related to trust.
H4 : Perceived quality is significantly and positively related to trust.

H5 : Trust mediates the relationship between communication and purchase behaviour.

H6 : Trust mediates the relationship between perceived price and purchase behaviour.

$H 7$ : Trust mediates the relationship between perceived quality and purchase behaviour

\section{Research Methods}

This study employed a quantitative research design by administering primary data collection instruments via a questionnaire survey. This study was conducted in a less-developed country, namely Yemen. A total of 1400 sets of questionnaires were distributed to school staff who represent local residents in four cities, which were Sanaa, Ibb, Taiz, and Aden. Responses from 711 respondents were received, representing about a $50 \%$ response rate. Past validated instruments were used to measure the specified variables. Eight items were used to measure communication, and seven items each to measure perceived price, perceived quality, and trust. Partial Least Squares, Structural Equation Modelling (PLS-SEM) was employed to analyse the relationships among the variables.

\section{Findings and Discussion}

This paper used two types of statistical validity tests, by using SEM/PLS and SPSS to analyse the data. Firstly, convergent validity was conducted to determine if the indicators in a scale load together onto a single construct. Secondly, the discriminant validity test was conducted to verify if the items developed to measure different constructs are definitely evaluating different constructs.

In line with the existing literature, this study measured the content reliability of the constructs 
to determine if the hypothesised items are actually measuring their constructs or otherwise (John \& Reve, 1982). The results shown in Table 1 indicate that the Cronbach's alpha values ranged from 0.624 to 0.756 , while the composite reliability values ranged from 0.766 to 0.841 . Both values for all variables are greater than the recommended value of 0.60 or higher, implying that the measures are reliable.

Table 1

Composite Reliability and Cronbach's Alpha

\begin{tabular}{lcc}
\hline Construct & Composite & Cronbach's Alpha \\
\hline Communication & 0.766 & 0.624 \\
Purchase Behaviour & 0.829 & 0.756 \\
Perceived Price & 0.841 & 0.746 \\
Perceived Quality & 0.823 & 0.677 \\
Trust & 0.787 & 0.661 \\
\hline
\end{tabular}

Table 2 shows that the values extracted for all the constructs explain $50 \%$ or more of the variance. The values ranged from 0.655 to 0.780 , satisfying the recommendation that the average variance extracted (AVE) value should be at least 0.50 for each construct (Barclay, Higgins \& Thompson, 1995; Bagozzi, Yi \& Philips, 1991; Holmes-Smith, 2001).

Table 2

\section{Discriminant Validity}

\begin{tabular}{lccccc} 
Construct & Communication & Purchase & $\begin{array}{c}\text { Perceived } \\
\text { Price }\end{array}$ & $\begin{array}{c}\text { Perceived } \\
\text { Quality }\end{array}$ & Trust \\
\hline Communication & 0.672 & & & & \\
Purchase Behaviour & 0.335 & 0.671 & & & \\
Perceived Price & 0.389 & 0.376 & 0.756 & & \\
Perceived Quality & 0.431 & 0.448 & 0.564 & 0.780 & \\
Trust & 0.529 & 0.420 & 0.439 & 0.480 & 0.655 \\
\hline
\end{tabular}

This study applied bootstrapping techniques embedded within the Smart PLS 3. Table 3 shows that the regression parameter estimates show three positive significant relationships, which are between communication and trust ( $\beta=0.392, \mathrm{~T}=4.99, \mathrm{P}<.0 .000)$, between perceived quality and trust $(\beta=0.233, \mathrm{~T}$ $=2.051, \mathrm{P}<0.000)$, and between trust and purchase behaviour $(\beta=0.320, \mathrm{~T}=3.529, \mathrm{P}<$
0.000). Therefore, Hypotheses 1, 2, and 4 are thus supported.

On the other hand, the results showed that perceived price has an insignificant relationship with trust $(\beta=0.144, \mathrm{~T}=1.419, \mathrm{P}<0.090)$. Thus, Hypothesis 3 is not supported. These findings are discussed in the context of actual and intended purchase of local brands in a less-developed country, such as Yemen. 
Table 3

Research Findings

\begin{tabular}{lcccccc}
\hline Hypothesis & $\beta$ & $\begin{array}{c}\text { Sample } \\
\text { Mean (M) }\end{array}$ & $\begin{array}{c}\text { Standard } \\
\text { Deviation } \\
\text { (STDEV) }\end{array}$ & $\begin{array}{c}\text { Standard } \\
\text { Error } \\
(\text { STERR })\end{array}$ & $\begin{array}{c}\text { T Statistics } \\
(\mid \mathrm{O} /\end{array}$ & P Values \\
STERR $\mid)$ & \\
\hline H1:Trust -> Purchase Behaviour & 0.320199 & 0.322329 & 0.090723 & 0.090723 & 3.529432 & 0.000 \\
H2:Communication -> Trust & 0.392305 & 0.384636 & 0.087181 & 0.087181 & 4.499867 & 0.000 \\
H3:Perceived Price -> Trust & 0.144685 & 0.159239 & 0.101915 & 0.101915 & 1.419665 & 0.090 \\
H4:Perceived Quality -> Trust & 0.232735 & 0.238166 & 0.113489 & 0.113489 & 2.050731 & 0.000 \\
\hline
\end{tabular}

Figure 1 shows the complete path of the relationship between the constructs, while Figures 2, 3, and 4 depict trust as a mediator between communication, perceived price, perceived quality, and purchase behaviour respectively.

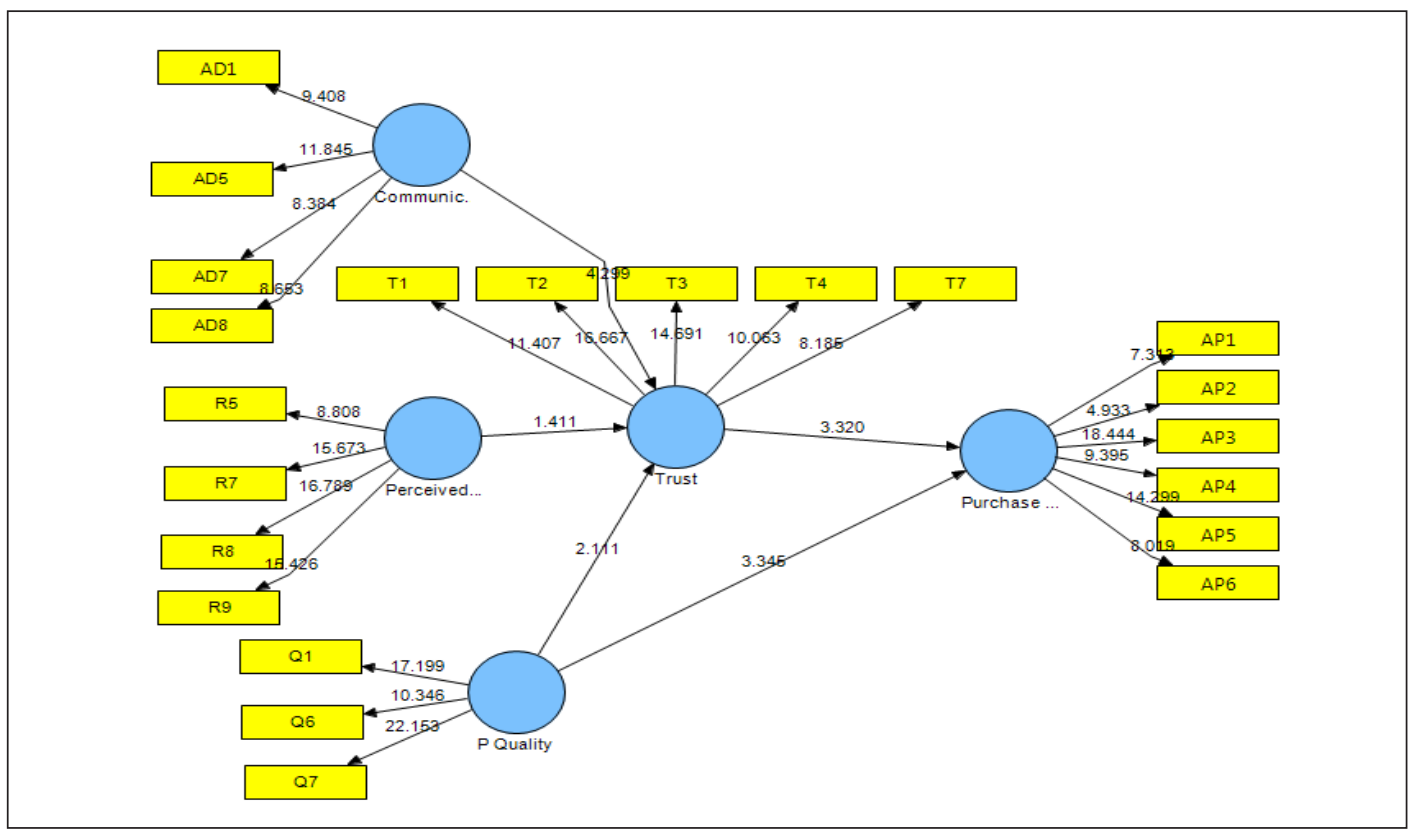

Figure 1. Hypothesised model of the study.

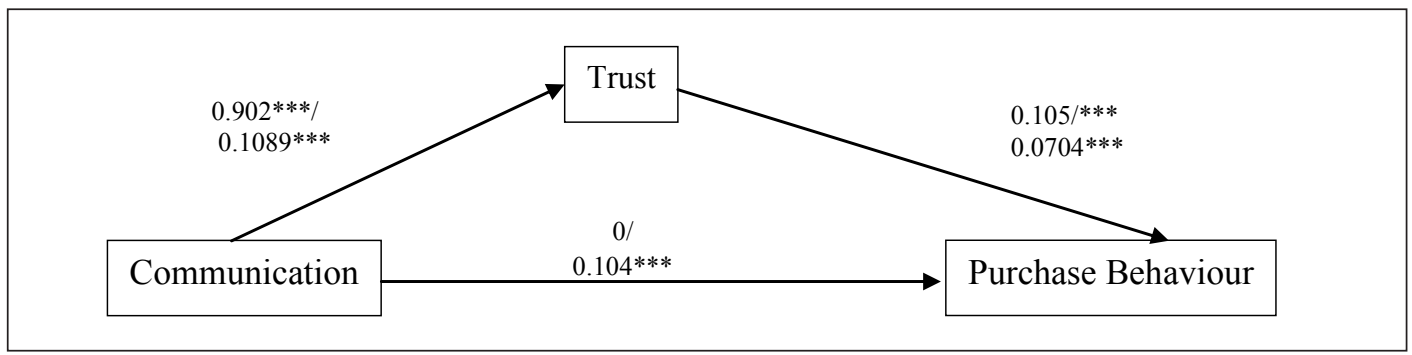

Figure 2. Trust as a mediator between communication and purchase behaviour. 
The analysis of mediating effect shown in Figure 2 shows that trust is a partial mediator between communication and purchase behaviour, so Hypothesis 5 is thus supported.
On the other hand, the result shown in Figure 3 reveals that trust is not supported as a mediator between perceived price and purchase behaviour. This implies that Hypothesis 6 is not supported.

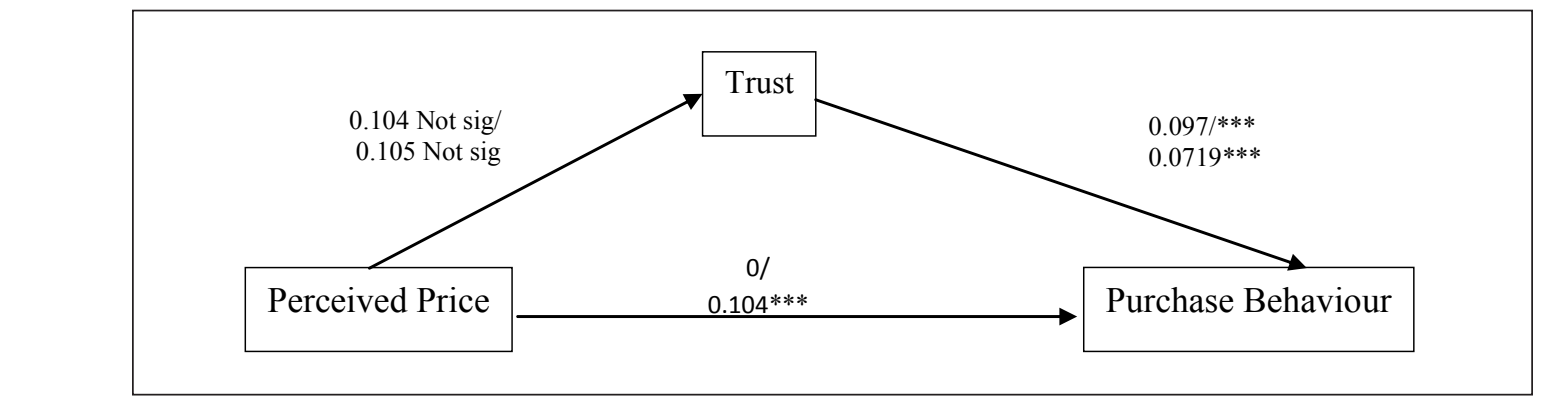

Figure 3. Trust as a mediator between perceived price and purchase behaviour.

In addition, the findings depicted in Figure 4 shows that trust is regarded as a partial mediator

between perceived quality and purchase behaviour. Thus, Hypothesis 7 is supported.

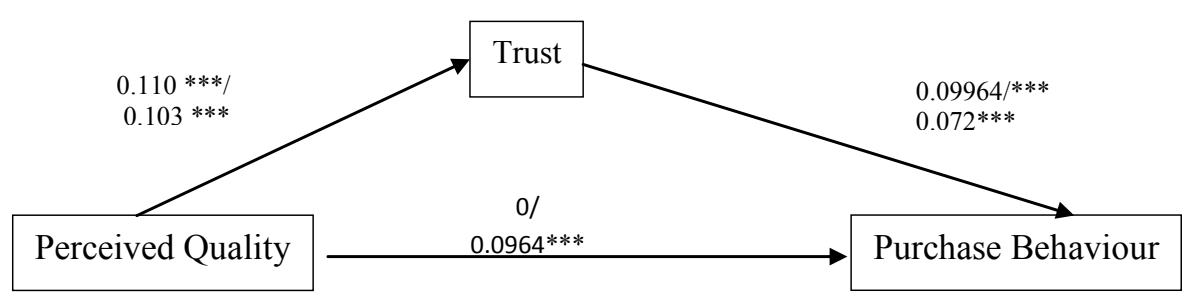

Figure 4. Trust as a mediator between perceived quality and purchase behaviour.

The findings from this research offer insights on the antecedents and consequence of brand trust. It provides evidence of the purchase behaviour of local brands of people in Yemen, a less-developed county, from the perspective of relationship marketing. To promote the market of local product brand among the people of the country, companies and the government should encourage and consider a high level of relationship marketing factors-namely product quality, communication, and trust-among its citizens. Producers and relevant government agencies alike may extend their influence over contextual factors that shape consumer attitudes toward local product brands. Awareness campaigns on the relative economic advantage of consuming locally made products can help.
Similarly, companies and the government should come up with more policies that will be supportive of the local producers and the government should encourage all companies to produce high quality local products. These may include policies like tax holiday to existing local firms, import duties on consumer goods, and production subsidies. These inevitably would contribute toward enhancing intended and actual consumption of local products.

\section{Conclusion}

This research established five significant paths, supporting five hypotheses: 1) brand trust and purchase behaviour of local brands, 2) 
communication and brand trust, 3) perceived quality and brand trust, 4) communication to brand trust to purchase behaviour of local brands, and 5) perceived quality to brand trust to purchase behaviour of local brands. Brand trust does not appear to mediate the relationship between perceived product price and purchase behaviour.

This research has a number of limitations that could create opportunities for future research. Firstly, future research directions could examine more antecedents or factors influencing the brand trust and purchase behaviour of local brands. These variables could include the satisfaction, loyalty, perceived value (Chiou, 2004; Valle, Silva, Mendes \& Guerreiro, 2006), brand equity motivations, service quality, reputation, availability, and many others.

Secondly, future research could conduct more related studies on the purchase behaviour of local brand settings in less-developed countries, since there are only a few past studies investigating the actual purchase behaviour in less-developed countries. Thirdly, a comparative research could be conducted to compare between Yemen and other countries' purchase behaviour of the local brands. Finally, it is recommended that future studies employ a qualitative method, such as in-depth interviews. By doing so, researchers may discover more factors that could influence consumers toward purchasing local brands in less-developed countries. This can be better achieved when the researchers build a trusted relationship with the respondents and speak their language.

\section{References}

Agbonifoh, B. A., \& Elimimian, J. U. (1999). Attitudes of developing countries towards country-of-origin brands of multiple brands. Journal of International Consumer Marketing, 11(4), 97-116.

Ahmed, Z. U., Johnson, J. P., Yang, X., Fatt, C. K., Teng, H. S., \& Boon, L. C. (2004). Does country of origin matter for lowinvolvement brands? International Marketing Review, 21(1), 102-120.
Ajzen, I., \& Fishbein, M. (1977). Attitudebehaviour relations: A theoretical analysis and review of empirical research. Psychological bulletin, 84(5), 888-918.

Al-Ekam, J. M. E. (2013). Actual purchase behaviour of local brand antecedents in Yemen: Mediating effect of purchase intention. (Doctoral Thesis, Universiti Utara Malaysia). Retrieved from http:// etd.uum.edu.my/3807/13/91138.pdf

Al-Ekam, J., Mat, N. K. N., Salleh, S. M., Baharom, N., Teh, T. R. T., Noh, N. A., \& Hussain, N. E. (2012). The influence of trust, advertising, family on intention and actual purchase of local brand in Yemen. American Journal of Economics, Special Issue (June 2012), 64-68.

Alvarez, B. A., \& Casielles, R. V. (2005). Consumer evaluations of sales promotion: The effect on brand choice. European Journal of Marketing, 39(1/2), 54-70.

Anderson, E., \& Weitz, B. (1989). Determinants of continuity in conventional industrial channel dyads. Marketing Science, 8(4), 310-323.

Armstrong, G., \& Kotler, P. (2009). Marketing. An introduction. (9th ed.). New Jersey: Prentice Hall.

Bagozzi, R. P., Yi, Y., \& Phillips, L. W. (1991). Assessing construct validity in organisational research. Administrative science quarterly, 36(3), 421-458.

Barclay, D., Higgins, C., \& Thompson, R. (1995). The partial least squares (PLS) approach to causal modelling: Personal computer adoption and use as an illustration. Technology studies, 2(2), 285-309.

Batra, R., Ramaswamy, V., Alden, D. L., Steenkamp, J., \& Ramachander, S. (2000). Effects of brand local and nonlocal origin on consumer attitudes in developing countries. Journal of Consumer Psychology, 9(2), 83-95.

Bell, D. R., Ho, T. H., \& Tang, C. S. (1998). Determining where to shop: Fixed and variable costs of shopping. Journal of Marketing Research, 35(3), 352-369. 
Brown, S. P., \& Stayman, D. M. (1992). Antecedents and consequences of attitude toward the ad: A meta-analysis. Journal of Consumer Research, 19(1), 34-51.

Burke, M. C., \& Edell, J. A. (1989). The impact of feelings on ad-based affect and cognition. Journal of Marketing Research, 26(1), 69-83.

Central Bank of Yemen. (2010). 2010 Annual Report of Central Bank of Yemen. Retrieved from http://www.centralbank. gov.ye/.

Chiou, J. S. (2004). The antecedents of consumers loyalty toward internet service providers. Information and Management, 41(6), 685-695.

Chung, J. E., \& Pysarchik, D. T. (2000). A model of behavioural intention to buy domestic products versus imported products in a Confucian culture. Marketing Intelligence and Planning, 18(5), 281291.

Crosby, L. A., Evans, K. R., \& Cowles, D. (1990). Relationship quality in services selling: An interpersonal influence perspective. Journal of Marketing, 54(3), 68-81.

Dash, J. F., Schiffman, L. G., \& Berenson, C. (1976). Risk and personality-related dimensions of store choice. Journal of Marketing, 40(1), 32-39.

Elliott, G. R., \& Cameron, R. C. (1994). Consumer perception of brand quality and the country-of-origin effect. Journal of International Marketing, 2(2), 49-62.

Farah, M. F., \& Newman, A. J. (2010). Exploring consumer boycott intelligence using a socio-cognitive approach. Journal of Business Research, 63(4), 347-355.

Ganesan, S. (1994). Determinants of long-term orientation in buyer-seller relationships. Journal of Marketing, 58(2), 1-19.

Granzin, K. L., \& Olsen, J. E. (1998). Americans' choice of domestic over foreign products: A matter of helping behaviour? Journal of Business Research, 43(1), 39-54.

Han, C. M. (1988). The role of consumer patriotism in the choice of domestic versus foreign products. Journal of Advertising Research, 28(3), 25-31.
Holmes-Smith, P. (2001). Introduction to structural equation modelling using LISREL. Perth: ACSPRI-Winter training Program.

Hunt, S. D., Arnett, D. B., \& Madhavaram, S. (2006). The explanatory foundations of relationship marketing theory. The Journal of Business and Industrial Marketing, 21(2), 72-87.

Jain, S. C. (1989). Standardisation of international marketing strategy:

Some research hypotheses. Journal of Marketing, 53(1), 70-79.

Jimenez, N. H., \& Martın, S. S. (2009). The role of country-of-origin, ethnocentrism and animosity in promoting consumer trust. The moderating role of familiarity. International Business Review, 19(1), 34-45

John, G., \& Reve, T. (1982). The reliability and validity of key informant data from dyadic relationships in marketing channels. Journal of Marketing Research, 517-524.

Juan, C., Ga, Z. A., \& Manuel, S. P. (2009). Factors influencing olive oil brand choice in Spain: An empirical analysis using scanner data. Agribusiness, 25(1), 36-55.

Kanso, A. (1992). International advertising strategies: Global commitment to local vision. Journal of Advertising Research, 32(1), 10-14.

Knight, G. A. (1999). Consumer preferences for foreign and domestic products. Journal of Consumer Marketing, 16(2), 151-162.

Levitt, T. (1993). The globalisation of markets. Readings in International Business: A Decision Approach, 1(1), 249-265.

Lumpkin, J. R., Greenberg, B. A., \& Goldstucker, J. L. (1985). Marketplace needs of the elderly: Determinant attributes and store choice. Journal of Retailing, 61(2), 1075 .

MacKenzie, S. B., Lutz, R. J., \& Belch, G. E. (1986). The role of attitude toward the ad as a mediator of advertising effectiveness: A test of competing explanations. Journal of Marketing Research, 23(2), 130-143.

MacKenzie, S. B., \& Lutz, R. J. (1989). An empirical examination of the structural antecedents of attitude toward the ad in 
an advertising pretesting context. The Journal of Marketing, 53(2), 48-65.

Marie, H., De, C., Patrick, D., Pelsmackera, B., \& Maggie, G. (2009). Relationship quality and the theory of planned behaviour models of behavioural intentions and purchase behaviour. Journal of Business Research, 62(1), 82-92.

McEachern, M. G., Schröder, M. J. A., Willock, J., Whitelock, J., \& Mason, R. (2007). Exploring ethical brand extensions and consumer buying behaviour: The RSPCA and the Freedom Food brand. Journal of Products and Brand Management, 16(3), 168-177.

Moorman, C., Deshpande, R., \& Zaltman, G. (1993). Factors affecting trust in market research relationships. Journal of Marketing, 57(1), 81-101.

Morgan, R. M., \& Hunt, S. D. (1994). The commitment-trust theory of relationship marketing. Journal of Marketing, 58(3), 20-38.

Nelson, P. (1974). Advertising as information. Journal of Political Economy, 82(4), 729-754.

Park, C. W., \& Young, S. M. (1986). Consumer response to television commercials: The impact of involvement and background music on brand attitude formation. Journal of Marketing Research, 23(1), 11-24.

Rousseau, D. M., Sitkin, S. B., Burt, R. S., \& Camerer, C. (1998). Not so different after all: A cross-discipline view of trust. The Academy of Management Review, 23(3), 393-404.

Shaw, D., \& Shiu, E. (2003). Ethics in consumer choice: A multivariate modelling approach. European Journal of Marketing, 37(10), 1485-1498.
Shoham, A., \& Makovec, B. M. (2003). Consumer ethnocentrism, attitudes, and purchase behaviour. Journal of International Consumer Marketing, 15(4), 67-86.

Sirdeshmukh, D., Singh, J., \& Sabol, B. (2002). Consumer trust, value, and loyalty in relational exchanges. Journal of Marketing, 66(1), 15-37.

Story, J., \& Hess, J. (2006). Segmenting customer-brand relations: Beyond the personal relationship metaphor. Journal of Consumer Marketing, 23(7), 406-413.

Synodinos, N. E., Keown, C. F., \& Jacobs, L. W. (1989). Trans-national advertising practices - A survey of leading brand advertisers in 15 countries. Journal of Advertising Research, 29(2), 43-50.

Valle, P., Silva, J. A., Mendes, J., \& Guerreiro, M. (2006). Tourist satisfaction and destination loyalty intention: A structural and categorical analysis. International Journal of Business Science and Applied Management, l(1), 25-44.

Vida, I., Dmitrovic, T., \& Obadia, C. (2008). The role of ethnic affiliation in consumer ethnocentrism. European Journal of Marketing, 42(3/4), 327-343.

Wang, C. L., \& Chen, T. X. (2004). Consumer ethnocentrism and willingness to buy domestic products in a developing country are setting testing moderating effects. Journal of Consumer Marketing, 21(6), 391-400.

Wu, S. I., \& Lo, C. L. (2009). The influence of core-brand attitude and consumer perception on purchase intention towards extended products. Asia Pacific Journal of Marketing and Logistics, 21(1), 174194. 